\title{
Strategy for improving the quality of education through meeting the standards manpower of education in junior high school
}

\author{
Tina Rosalina ${ }^{1}$, Happy Fitria ${ }^{2}$, Achmad Wahidy ${ }^{2}$ \\ ${ }^{1}$ Sekolah Menengah Pertama Negeri 1 Rambang, Indonesia \\ ${ }^{2}$ Universitas PGRI Palembang, Indonesia
}

\begin{tabular}{l} 
Article Info \\
\hline Article history: \\
Received Jul $16^{\text {th }}, 2021$ \\
Revised Aug $9^{\text {th }}, 2021$ \\
Accepted Aug $30^{\mathrm{h}}, 2021$ \\
\hline
\end{tabular}

\section{Keyword:}

Strategy

Quality Improvement of

education

Education standards

Educational personnel

\begin{abstract}
PT)
How much influence is the strategy for improving the quality of education through meeting education standards and education personnel. The purpose of this study is to find and describe efforts to improve education standards and education personnel in schools in terms of: planning, implementing and supervising education, influencing, directing teachers and school staff in improving the quality of education. As stated in the National Education Standards (SNP) article 1 No. 17 of Law 20/2003 on National Education System and article 3 of Government Regulation No. 19 Year 20015 that: "Where SNP functions as the basis for planning, implementation and supervision of education at the level of education to realize a national education that is of good quality and aiming at guaranteeing the quality of national education in the framework of educating the life of the State and forming a dignified national civilization ". In expressing these things the writer uses a qualitative research approach. To extract data and information from informants, the authors used participant observation, in-depth interviews, and documents in the research data collection process. The research results revealed that; in meeting education standards and education personnel can influence teachers and school management staff so that what is done is aimed at school success and achievement, in order to improve the quality of education at SMP Negeri 1 Rambang Muara Enim Regency.
\end{abstract}

(C) 2021 The Authors. Published by IICET.

This is an open access article under the CC BY-NC-SA license

(https://creativecommons.org/licenses/by-nc-sa/4.0

\section{Corresponding Author:}

Rosalina, T.,

Sekolah Menengah Pertama Negeri 1 Rambang, Indonesia

Email: tinarosalina26@gmail.com

\section{Introduction}

Currently, the quality of education in Indonesia has indeed seen a lot of progress, with various programs carried out by the government to continue to improve the quality of education and the quality of its educators. The government has planned programs in the short term as well as in the long term so that the program to improve the quality and quality of education in Indonesia occurs in a sustainable manner. However, based on research conducted by the international survey institute PIRLS (Progress in International Reading Literacy Study), or commonly known as the international reading program for students in schools. This study was coordinated by IEA (The International Association for The Evaluation of Education Achievement) based in Amsterdam, The Netherlands. This survey is conducted every five years, which on April 8, 2013, PIRLS shows the results of the survey, namely from 45 countries that are members of the IEA, Indonesia is ranked 41 with a score of 405 . This value is a value that is below the average value International (500 with standard 
deviation $=100$ ). This shows that education in Indonesia is still very low, seen from the reading scores of students in educational institutions.

In contrast to the results of recent research conducted by the Program for International Assessment (PISA), which examines the quality of education, which shows that the quality of education in Indonesia is only able to rank 64th out of 65 member countries of PISA. This result is the result of a study conducted by the PISA institution which is held every three years. In other words, the quality of Indonesian education is the second worst in the world. This can see the results of mathematical competence, Indonesia only gets a score of 375 and a score of 382 for science. The reading level of Indonesian students, based on this study, only gets a score of 396. When compared with a number of countries in the ASEAN region which are also members of PISA such as Malaysia and Singapore, the quality of education in Indonesia is even far behind, even though in fact Indonesia has experienced many developments, it will but the quality of education is still low. And looking at the scores that have been obtained by the results of these studies, where reading and science scores get the lowest score compared to other countries, this raises a big question, what is the quality of the teaching force? so that the government program to increase the standard of teaching and education personnel seems meaningless, because it does not show positive results for the development of national education. Therefore, the most important thing in improving the education system in Indonesia is to improve the quality of the teaching staff first, so that the quality of the educational institutions will automatically develop.

Improving the quality of education is one of the main pillars in developing education in Indonesia, because if education is of good quality, it will produce intelligent and competitive human resources. To realize a sustainable education quality improvement program, this is made clear by the existence of Government Regulation (PP) No. 19 of 2005 on National Education Standards (SNP), which are the minimum criteria for the education system in all regions in Indonesia (Article 1 Number 17 of Law 20/2003 concerning the National Education System and article 3 PP.19 / 2005 concerning SNP), where the SNP functions as the basis for planning, implementing, and supervising education at every level of education to realize quality national education, and aims to guarantee the quality of national education in order to make it educated State life and form a dignified civilization.

The components of the National Education Standards (SNP) include: (1) graduate competency standards (2) content standards (3) teacher and educational staff standards (4) process standards (5) facilities and infrastructure standards (6) financing standards (7) standard management and (8) assessment standards. From the results of the data mentioned about the evaluation of trends in the quality of education in Indonesia, each education unit gives a positive and feasible response to implementing the National Education Standards.

For more details, it can be seen from the following achievement figures: $98.40 \%$ content standard, $90.99 \%$ process standard, $65.10 \%$ graduate standard, $80.27 \%$ teacher and education staff standard, $83.03 \%$ infrastructure standard, management standard $94.63 \%$, financing standard $88.36 \%$, assessment standard $85.97 \%$. Based on these results for junior high schools, both public and private, the average achievement of national education standards has reached $85.97 \%$ of the expected. From the data presentation above, it can be seen that the level of difficulty to achieve SNP, is the passing standard (65.10\%) is in the first rank which is very difficult to achieve, this poses big questions for the teaching and learning system and process that takes place in schools. After the graduation level, the standard of educators and education staff (80.27) is in the second rank which is also difficult to achieve, even though educators are one of the important pillars in education that determines everything in the development of the quality of education itself.

[1] Teacher performance can be described as a task performed by a teacher at a certain period in the school system to achieve organizational goals [2] Starting from the ranking of education quality in Indonesia produced by PISA, it turns out that the standard of teaching and education personnel which ranks second in the level of difficulty that must be achieved, proves that the quality of education is low due to the low quality standards of teaching personnel and education. Because so far, the government has only been able to provide training and development, but has not been able to approach teachers emotionally, that is why many educators do not have the desire to develop education, because they consider their work only as a profession, without having a soul as educators and ownership of institutions. education. Teachers have academic qualifications, competencies, teacher certificates, are physically and mentally healthy, and are able to realize the goals of national education. Teacher competence includes pedagogic competence, personality competence, social competence and professional competence obtained through competency education that must be possessed by every teacher at any level of education [3]

Judging from the problems that have been rooted in the education system in Indonesia in order to achieve national standards for teacher and education standards, SMP Negeri 1 Rambang also strives to meet national standards by continuing to make improvements and developments in its education system, one of which is by 
empowering educators and education through various ways. For the sake of the development of existing education, SMP Negeri 1 Rambang also strives for educators and education staff to continue to hone their knowledge according to their respective competencies. According to preliminary observations, what schools do in improving the quality of their educators and education starts from the recruitment process for educators and education personnel, in addition to meeting the standards set by the government, namely academic qualifications, teacher competency standards (pedagogical, personality, professional, and social), physically healthy and spiritual, and can achieve the goals of national education. Therefore, the principal tries to develop the school as well as possible, but without leaving the values of politeness. Therefore, this policy was taken because it was a form of effort from the principal in developing the school, through developing the potential of teaching staff at SMP Negeri 1 Rambang. In making these policies, of course the principal will not override the policies regarding the standards of teaching and education personnel that have been set by the government.

In order to meet the standards set by the government regarding educators and education personnel, the school strives to continue to develop existing human resources, with the implementation of the Subject Teacher Conference (MGMP) on a weekly basis which is held every Thursday, enrichment of educators for educational personnel. conducted by supervisors every two weeks, and official forums such as education and training and teacher development training according to their competence. Educators in schools will be appointed to attend training or training according to their competence. For example, if the local government holds a seminar on the empowerment of teachers in religious subjects, then the teachers who will be sent are teachers whose competences are in religious subjects. This is so that the implementation of teacher development training is right on target, and in accordance with the competencies of the teachers who want to be developed.

In an effort to achieve the standards set by the National Education Standards Agency (BSNP), the head of SMP Negeri 1 Rambang has again made a policy for teaching staff and education. Namely, if there are educators and education staff who do not meet the standards in carrying out the teaching and learning process at SMP Negeri 1 Rambang, the school principal will call and be advised and even given a warning to improve their performance. what is meant is that it does not meet the standards of the teaching and learning process at SMP Negeri 1 Rambang, namely the indiscipline of the teaching staff and education in attending school, making teaching devices and so on. The principal's policy towards undisciplined teachers within the time limit set by this school is a form of the principal's efforts to improve the quality of teaching and education personnel at SMP Negeri 1 Rambang, considering that the position of teachers is the most essential human resource in education. This policy was taken, considering that the most difficult thing to overcome by SMP Negeri 1 Rambang is the discipline of teaching staff and their education to come to school on time. Therefore, the principal's policy has been established since 2015 in order to create a school that not only seeks to develop students, but must first start from its educational staff. These efforts are made by the school, so that the existing teaching and education staff owned by the school can achieve the standards set by the BSNP, regarding the standards of educators and education personnel, and the standards set by the school, namely the spirit of ownership of the school. Because the problem of developing human resources in education is a classic problem that is very difficult to overcome. With the efforts that have been made, the head of SMP Negeri 1 Rambang hopes that educators and education personnel are able and can achieve these standards. this is so that education in schools will be of higher quality, so that the programs of SMP Negeri 1 Rambang will provide positive results for the value of the school development process.

As an effort to increase the standards of teaching and education personnel, educators are also required to hone their religious abilities, this applies to all stakeholders at SMP Negeri 1 Rambang, in order to maintain a balance between general science and religion of the teaching staff at SMP Negeri 1 Rambang. And in order to integrate religious values in each existing subject. This effort is made so that the religious spirit of each individual will be more attached, so that it is hoped that it can form the character of a professional educator who is full of religious spirit. To achieve the standards set by the government, of course, school efforts need to be carried out continuously, and it is disclosed by the principal that educators and education personnel who are not in accordance with their competence will be sent back to school in accordance with existing regulations. This is a government program that has been socialized to school principals, in order to empower education personnel, to improve the quality of education in the regions. With this well-planned effort, it is hoped that the competence of educators and education personnel at SMP Negeri 1 Rambang can increase, this is also an effort to improve the quality of education in schools that are located far from district cities. In making this effort, of course, must be supported by the discipline, awareness, and spirit of an educator that must be possessed by an educator in a school institution. These efforts will not be successful if the stakeholders at SMP Negeri 1 Rambang do not have a sense of responsibility for education development. Problems will arise repeatedly if only school principals have good will, and educators only go according to their own wishes. To avoid this from happening, the head of SMP Negeri 1 Rambang sets standards for teaching staff and 
education, in addition to the standards set by the government. This is done so that existing teaching staff can meet the standards set by the government and of course become school standards.

The interesting thing about this problem is that there are standards set by the principal in addition to the standards from the government, how to make school and government policies go hand in hand, so that schools can develop. Of the eight standards that have been implemented in schools, the less achieved results are the passing standard $(65.10 \%)$ which is the main ranking which is very difficult to achieve, the standard of education and education personnel (80.27\%) is in the second rank which is also difficult to achieve, the standard of facilities and infrastructure (83.03\%) in the third rank have not been maximized. The policies of the school are what make the school a reference for other schools in the Rambang sub-district. Therefore, the authors are motivated to conduct research on "Strategies for Improving the Quality of Education through Fulfillment of Standards for Educators and Education Personnel at SMP Negeri 1 Rambang".

It is in line with research conducted by Arnal, Fitria and Martha. 2020. Journal of Student Management Tambusai Education in Improving Organizational Quality. . Volume 4, Issue 3, Pages: 1820-1827. Research that examines student management in improving the organization at SMP Muhammadiyah Prabumulih City by looking at how student management is implemented, what student management efforts are in improving organizational quality and what are the supporting and inhibiting factors for student management. This research uses descriptive research with a qualitative approach, in data collection using the method of observation, interviews, and documentation. Then the data were analyzed using qualitative descriptive data analysis techniques to analyze data, both data from observations, interviews, and documentation, by describing or describing the data. The results of this study include the implementation of student management at SMP Muhammadiyah Prabumulih City not only carried out by student students but also by collaborating with other parties in two ways, namely taking part in basic student leadership training, holding regular gatherings and giving students the confidence to manage the organization and its activities . The supporting factors are the high intensity of coordination, professional attitude and discipline. Meanwhile, the inhibiting factor is the lack of communication. The equation of this research is about improving school quality and qualitative methods. The difference is the time and place of study.

\section{Method}

This type of research is a qualitative research method, according [4], a qualitative research method is a research method used to examine the conditions of a natural object, where the researcher is the key instrument. [5] that "a method is defined as a method used to achieve predetermined goals."

\section{Results and Discussions}

\section{The leadership of the principal in improving the quality of education at SMP Negeri 1 Rambang, Muara Enim Regency.}

The results of interviews with the principal, namely Mr. Misar, S.Pd in relation to the strategy of improving the quality of education through meeting education standards and education personnel at SMP Negeri 1 Rambang, respondents stated that: that they have carried out change management in improving the quality of education of this school, namely by how decision-making involves many parties, such as teachers and school committees, decision-making through quality clusters consisting of senior teachers in science and learning methodology, school committee members consisting of experts or established practitioners, the control team because the principal stated that this This is change management, then the author asks the principal what strategies are carried out by the principal in improving the quality of education and why it is done in the decision-making process, the principal stated:

"The decision-making process is carried out by listening to opinions during coordination meetings between school principals, teachers and administrative staff with the aim that any decisions made by school principals will not appear based on unilateral decisions."

In order to improve quality effectively and efficiently, it is necessary to be supported by qualified Human Resources (HR). Human Resources Development is a process of enhancing human capabilities so that they are able to make breakthroughs. The process of developing Human Resources must touch various areas of life that are reflected in the personal leadership, including the leader of SMP Negeri 1 Rambang. The principal is one of the components of education that has the most role in improving the quality of education. As stated in Article 12 paragraph 1 PP 28 of 1990 that: "The principal is responsible for the implementation of educational 
activities, school administration, coaching other educational personnel, and the utilization and maintenance of facilities and infrastructure.

The results of interviews and observations with school principals, teachers, and committees: Empirical facts show that the principal of SMP Negeri 1 Rambang has carried out duties according to their role and function as educational leaders. This phenomenon is caused because it meets the standards of education and education personnel. All of this can be seen from the increase in the quality of education due to the increase in the educational process which ultimately has an impact on the output and outcome of education, how to improve the quality of education by meeting the standards of education and education personnel.

The Principal as a Leader is based on the findings in the field that during the leadership of the current school principal, he has achieved sufficient achievements both in the academic and non-academic fields, including: 1) In the UKS (School Health Business) assessment in previous years, it was ranked third in Provincial level and since the current headmaster leadership. 2) Based on the findings of the author's observations that: "The principal in leading the school has been able to make decisions for internal and external school affairs, is willing to hear and accept suggestions and criticisms from school members, and has a commitment. 3) The principal is an innovator based on the findings in field that the principal of SMP Negeri 1 Rambang has enough new ideas such as implementing SNP-based schools such as the absence of additional computers, provision of LCD projectors and laptops, even damaged computers and laptops are immediately repaired so as to accelerate the activities of education personnel, school implementation towards SNP is running well even though there are still gaps here and there. One way of doing this is to make schools go to quality schools, it can be seen that there is a follow-up to these activities. As stated by the head of the school committee, namely that: "People who have joined the school committee have been involved in any activity. Based on the findings of the author's observation that: "The principal has cultivated entrepreneurial behavior seen from the development of school businesses in the form of well-managed school cooperatives.

\section{Discussion}

The National Education Standards (SNP) are the minimum criteria regarding the education system in all jurisdictions of the Republic of Indonesia. SNP serves as the main guideline in planning, implementing and supervising education in the context of realizing quality national education. The National Education Standards include eight criteria that must be met in an effort to achieve quality education. The eight national standards consist of: 1. Content Standards, 2. Process Standards, 3. Graduate Competency Standards, 4. Educators and Education Personnel Standards, 5. Facilities and Infrastructure Standards, 6. Management Standards, 7. Financing Standards, 8. Educational Assessment Standards.

1. Leadership of the principal in improving the quality of education.

Principal leadership means empowering and utilizing existing resources that can be held efficiently and effectively to achieve the vision and mission of the school. The principal is responsible for the running of the school institution and its activities. The principal is at the forefront of carrying out his leadership and his success can be measured. The final product of principal leadership is school performance that changes both for teachers and students. The change of teachers and students from not knowing to knowing, from inexperienced to experienced, from being unable to become able, from being underachieving to being accomplished. Meanwhile, the principal's leadership target is to improve the quality of education. So, the leadership of the principal has a strong role in shaping the quality of the people he leads to become the nation's next reliable generation. The implementation of the leadership of the principal of SMP Negeri 1 Rambang should be as follows: a. Principal as Educator (Educator), b. Head of school as Manager, c. Principal as Administrator, d. Principal as Supervisor, e. Principal as a Leader (Leader), f. Principal as Innovator, g. Principal as Motivator,.

Achievement of school achievements, the Principal of SMP Negeri 1 Rambang in an effort to improve school achievement does not carry out curricular, co-curricular or extracurricular activities besides that there is also no availability of various needs needed in learning such as procurement of laptops, computer laboratories, multimedia rooms and other devices. This is a support for improving the quality of schools which eventually become less qualified schools. Based on the results of his study, the Southern Regional Education Board (SREB) (Source: adaptation from: The Principal Internship: How Can We Get It Right?, Www.sreb.org.) Identified 13 critical factors related to the success of school principals in developing student learning achievements are: Creating a mission that is focused on efforts to improve student achievement, through curriculum and learning practices that allow for increased student achievement, high expectations for all students in learning subject matter at a higher level, appreciate and encourage the implementation of good learning practices, so as to motivate and improve student learning achievement, understand how to lead a school organization, where all 
teachers and staff can understand and care for their students, Utilizing data to initiate efforts to continuously improve student achievement and educational practice in schools and in the classroom, keep everyone focused on student achievement, Making parents as partners and building collaboration for the benefit of student education, understand the change process and have the leadership to be able to manage and facilitate the change effectively, understand how adults learn (read: teachers and staff) and know how to promote meaningful change so that quality professional development is formed in a sustainable manner for the benefit of students, utilizing and managing time to achieve school improvement goals and objectives through innovative ways, acquire and use various resources wisely, seek and obtain support from government, community leaders and parents for various school improvement agendas.

2. Continuous learning and collaborating with peers to develop new research and proven educational practices.

Constraints and ways to overcome "Quality education if it is in accordance with what is expected by the community (bench mark) can be met. If a school has achieved competitive quality standards both at national and international standards. Quality improvement will be fulfilled, if human resource development is maintained so that their professional quality is maintained ". [6] The principal can know how the process, work and implementation of a program according to the plan, how, results and time of completion can be monitored in order to obtain actual progress information. Anticipation can be made for things that are not according to plan. So the school as an organization in improving quality must look at all aspects of the school component. Principal supervision is the answer to all of that. As a manager / leader the principal is responsible and sure that the activities that occur in the school are working on the right plan and working on the plan correctly. So the vision and mission of the school must be understood first before becoming a starting point for predictions and before being disseminated. The principal can make predictions and design appropriate anticipatory measures. In addition, a professional performance is needed, such as proficiency in using educational philosophy, psychology, leadership science and anthropology and sociology. If seen from the description above, the obstacles faced by the principal of SMP Negeri 1 Rambang in carrying out his leadership have not been resolved properly with the principles developed by Ki Hajar Dewantara, namely "ing ngarso sung tuladho, ing madya mangun karsa, tut wuri handayani" besides It also provides intensive guidance and coaching according to the opinion of [6] who says that: "efforts to increase professional skills can be done by providing professional assistance to teachers in the form of refresher, consultation, guidance and possible activities".

\section{Conclusions}

Based on the analysis of research data on strategies for improving the quality of education through meeting education standards and education personnel at SMP Negeri 1 Rambang, it can be concluded as follows. National Education Standards have a function as a reference or basis in the planning, implementation and supervision of the quality national education.The National Education Standards aim to ensure quality national education in order to educate the nation's life, to form a dignified national character and civilization. National Education Standards are implemented in a planned, directed and sustainable manner in accordance with the common needs and changes in national and global life. The principal of SMP Negeri 1 Rambang in carrying out his leadership duties has carried out his roles and functions as educators, managers, administrators, supervisors, leaders, innovators and motivators. In addition, the Principal of SMP Negeri 1 Rambang must have determination, enthusiasm, competence / ability, as well as a weakness to use strengths, face obstacles (Weaknesses), take advantage of opportunities (Opportunities), and face challenges (Threats), in addition also must have the ability to build relationships with existing stakeholders.

In terms of achievement, schools make various programs that are packaged through coaching and activities that are both intra and extra-curricular as well as through career guidance as the findings in research show that the achievements of SMP Negeri 1 Rambang are not good, marked by academic and non-academic achievements at the level. districts and districts that have not had satisfactory results recently. In addition, there is public recognition which is shown by the lack of enthusiasm / number of students and the lack of community and alumni participation in providing assistance for the progress of schools and the fulfillment of existing infrastructure. In overcoming the various obstacles that exist, the Principal of SMP Negeri 1 Rambang must coordinate with existing stakeholders, training, training, upgrading, workshops, supervision, school meetings, committee meetings, presenting resource persons, providing guidance. So that the existing obstacles do not interfere with the running of the school programs that are made. The principal's strategy in improving the quality of education is based on the planning carried out by the principal, namely planning school programs that refer to 8 educational standards, increasing the professionalism of teachers in schools. Educators 
are the spearhead of the success of education, so they are required to meet academic qualifications and competencies as learning agents, physically and mentally healthy. In addition to teaching staff, educational personnel also have a major role in realizing quality education. The main role of education personnel is to provide technical services to support education in educational units.

\section{References}

[1] Zulkifli. 2010. Contribution of Teacher Creativity and School Principal Supervision on Teacher Performance in SMP Negeri Lubuk Basung District, Agam Regency, Padang: Thesis of the Postgraduate Program of Padang State University

[2] Adeyemi, 2011. "Principals 'Leadership Styles and Teachers' Job Performance in Senior Secondary Schools in Ondo State, Nigeria". Current Research Journal of Economic Theory, Vol. 3, No. 3, pp. page: 84-92 accessed from https://pdfslide.net/documents/bab-v-kes]-imlikasi-dan-saran-a-v-dan-lampiranpdf-104-inyoman-rauh.html. On 11/11/2020. 5:05 pm. Wow. Bandung: Alfabeta.

[3] Hamalik, Oemar. 2013. Teaching and Learning Process. Bandung: Sinar Baru Algesindo.

[4] Sugiyono. 2010. Statistics for Research. Fifth Print. Bandung: Alfabeta.

[5] Djamarah. 2010. Research Methods and Statistics. Jakarta: Rajawali Press.

[6] Sagala, Syaiful. 2009. Professional Capabilities of Teachers and Education Personnel. 